\title{
Recent Developments and Future Trends of Industrial Agents
}

\author{
Paulo Leitão ${ }^{1,2}$ and Pavel $\mathrm{Vrba}^{3}$ \\ ${ }^{1}$ Polytechnic Institute of Bragança, Campus Sta Apolonia, Apartado 1134, \\ 5301-857 Bragança, Portugal \\ pleitao@ipb.pt \\ ${ }^{2}$ Artificial Intelligence and Computer Science Laboratory, R. Campo Alegre 102, \\ 4169-007 Porto, Portugal \\ ${ }^{3}$ Rockwell Automation s.r.o., Pekarská 10a, 15500 Prague 5, Czech Republic \\ pvrba@ra.rockwell.com
}

\begin{abstract}
The agent technology provides a new way to design and engineer control solutions based on the decentralization of control over distributed structures, addressing the current requirements for modern control systems in industrial domains. This paper presents the current situation of the development and deployment of agent technology, discussing the initiatives and the current trends faced for a wider dissemination and industrial adoption, based on the work that is being carried out by the IEEE IES Technical Committee on Industrial Agents.
\end{abstract}

Keywords: Multi-agent systems, Industrial Agents, Industrial applications.

\section{Introduction}

The agent technology has been identified as a suitable approach to address the current requirements for modern control systems in industrial domains, such as automation, manufacturing, telecommunication, logistics and traffic control. It leverages the benefits of multi-agent systems, distributed computing, Artificial Intelligence (AI) techniques, and semantics. The key drivers for this effort are the potential benefits of agent-based industrial systems, namely in terms of autonomy, robustness, scalability, re-configurability and productivity [1-2], all of which translate to a greater competitive advantage. Many observers believe that the agent technology represents the most important new paradigm for software development since object-orientation [3], providing a new way to design and engineer control solutions based on the decentralization of control over distributed structures [4].

The applicability of agent technology in industrial environments requires a shift in the automation vision, since nowadays industrial applications are centred in rigid structures based on Programmable Logic Controller (PLC) solutions and on the IEC 611313 standard. This fact slows down the real and industrial deployment of the agent technology. As suggested by [5], the easiest way is to preserve the current low-level control that already use state of art industrial control based on PLCs running IEC 61131 control programs, guaranteeing real-time responsiveness, and create an agent layer on top of it to provide intelligence and adaptation.

V. Mařík, P. Vrba, and P. Leitão (Eds.): HoloMAS 2011, LNAI 6867, pp. 15-28, 2011.

(C) Springer-Verlag Berlin Heidelberg 2011 
Several efforts have been performed both in academic and industrial environments to answer this challenge. This paper intends to summarize the current situation in industrial agents. Namely it reports the existing industrial applications of agent technology and discusses the existing initiatives that have been established to increase the industrial adoption of this technology. The paper also points out some future challenges for a wider industrial adoption. The objective of the paper is not to survey all deployed agent-based applications but instead to report those for the industrial automation field, covering also other related areas such as logistics and material handling. This work reflects the authors' experience in the area, through developing agent-based applications for manufacturing domain, participating in numerous international conference and workshops related to the topic (such as HoloMAS and AAMAS series) and chairing the IEEE Industrial Electronics Society (IES) Technical Committee on Industrial Agents (http://www.tcia.ieee-ies.org/).

This paper is organized as follows. First, Section 2 surveys the existing industrial applications of agent technology and Section 3 describes the on-going R\&D projects handling the industrial application of agent technology and discusses the existing initiatives to increase the adoption of this technology. Finally, Section 4 discusses the current situation of industrial agents and points out some future challenges.

\section{Industrial Applications of Agent-Based Systems}

The agent technology is being applied in industrial solutions that range from manufacturing to logistics passing by material handling. This section provides a summary of the most well-know industrial applications reported in the literature (for a complementary analysis, refer to several previous surveys [2-3;6-8]). The compilation of such agent-based applications is not an easy task, mainly because the few industrial applications cover a wide range of domains and the majority of reported applications are found in academic and laboratorial environments and not in real plants.

\subsection{Manufacturing}

The manufacturing environment, covering different application domains like manufacturing control, manufacturing scheduling and production planning, is suitable to accommodate agent-based applications. Table 1 summarizes the industrial application of agent technology in this domain.

The Production 2000+ project applied agent technology in a production line for producing cylinder heads for four-cylinder diesel engines at the Daimler Chrysler factory plant in Stuttgart, Germany. The agent-based solution, called FactoryBroker and developed in cooperation with Schneider Automation GmbH [9], was in operation for five years up to the end of the life-cycle of the targeted product, being reported an increase of productivity of 20\% [10]. The main test-case of the MASCADA project was the development of an agent-based control, based on the PROSA (Product-Resource-Order and Staff Architecture) reference architecture [11], for a section of the painting center in the Daimler-Benz AG passenger-car plant in Sindelfingen, Germany, covering two painting steps and recovery procedures used to produce a perfectly painted car body [12]. 
Table 1. Industrial applications in manufacturing domain

\begin{tabular}{|c|c|c|c|}
\hline Designation & Company involved & Domain & Type \\
\hline Production 2000+ & $\begin{array}{l}\text { Daimler Chrysler, } \\
\text { Schneider }\end{array}$ & Manufacturing control & Industry \\
\hline Car body painting & Daimler-Benz & Manufacturing control & Industry, prototype \\
\hline BHP Billiton & Rockwell & Process control & Industry \\
\hline Chilled Water System & Rockwell & Distributed control & Industry, prototype \\
\hline Cambridge packing cell & U. Cambridge & Manufacturing control & Lab test bed \\
\hline FABMAS & $\begin{array}{l}\text { Technical University of } \\
\text { Ilmenau }\end{array}$ & Manufacturing control & Industry \\
\hline PS-Bikes & Universita de Genova & Manufacturing control & Industry, prototype \\
\hline Axion-Holding & Magenta & $\begin{array}{l}\text { Manufacturing } \\
\text { scheduling }\end{array}$ & Industry \\
\hline Shop Modelarna Liaz & $\begin{array}{l}\text { Certicon, Gerstner } \\
\text { Laboratory }\end{array}$ & Production planning & Industry \\
\hline SkodaAuto & $\begin{array}{l}\text { Gedas, Certicon, } \\
\text { Gerstner Laboratory }\end{array}$ & Production planning & Industry \\
\hline Agent Steel System & $\begin{array}{l}\text { Saarstahl AG, DFKI } \\
\text { Gmbh }\end{array}$ & Production planning & Industry \\
\hline SDM Laboratory & Yokogawa & Machinery control & Lab test bed \\
\hline NovaFlex & Uninova & Manufacturing control & Lab test bed \\
\hline ADACOR & $\begin{array}{l}\text { Polytechnic Institute of } \\
\text { Braganca }\end{array}$ & Manufacturing control & Lab test bed \\
\hline ABAS & $\begin{array}{l}\text { Tampere University of } \\
\text { Technology, Schneider } \\
\text { Electric }\end{array}$ & Manufacturing control & Lab test bed \\
\hline OntoReA & $\begin{array}{l}\text { TU Wien, Rockwell } \\
\text { Automation, COPA- } \\
\text { DATA }\end{array}$ & Manufacturing control & Lab test bed \\
\hline
\end{tabular}

The Rockwell Automation's first industrial application of the agent technology was in the mid 90s at the steel rod bar mill of the BHP Billiton in Melbourne, Australia, aiming to increase the machine utilization [13]. The agent-based solution was not used to direct control but instead to provide on-line recommendations of suitable resource configurations and control actions to the plant operator, mainly due to safety concerns. Another application developed by Rockwell Automation was an agentbased control system for the chilled water systems and the heating, ventilation and air conditioned (HVAC) systems of the US Navy ships [14]. The physical layout of the tested system was a scaled-down version of a real U.S. Navy ship.

Another application of industrial agents was the implementation of a holonic control system to assembly Gillete ${ }^{\mathrm{TM}}$ packages into customer-tailored gift boxes at a laboratorial holonic packing cell of the University of Cambridge [15]. Two different control solutions, developed by using JACK ${ }^{\mathrm{TM}}$ and JADE agent platforms respectively, considers holons to represent the physical components of the system and integrates Radio-Frequency Identification (RFiD) technology by using electronic tags embedded in discrete units, replacing the traditional barcodes. 
FABMAS (FAB Multi-Agent System) is a PROSA-based agent system for production control of semiconductor wafer fabrication facilities [16], using a discrete event simulator AutoSched AP to simulate the behaviour of the wafer fabrication shop floor. PS-Bikes is a project that developed a multi-agent scheduling and control system for manufacturing of custom bikes by using the JADE framework [17].

Magenta Technology implemented a multi-agent system for real-time scheduling and optimization of factory workshop resources at the Axion-Holding company, located in Izevsk, Russia, which is one of the biggest manufacturing companies of electronics in Russia. The system is being in its initial operation phase but it is expected to increase the workshop efficiency by $15-20 \%$ [18]. A manufacturing execution system (MES) using the holonic manufacturing systems (HMS) concepts is developed, using the JADE framework, for the American Glass Product (AGP) company that produces laminated security glass for automotive application [19].

ExPlanTech agent-based production planning framework was used for the implementation of several industrial applications, namely for the mass production planning in the SkodaAuto motor assembling plant and for planning the projectdriven production process of products produced from one design at the Modelarna Liaz, both in Czech Republic [5]. Also in the production planning domain, Saarstahl AG and DFKI Gmbh developed the Agent Steel System for on-line planning of the steel production using the InteRRap multi-layered generic agent architecture [20].

Yokogawa Electric Corporation used autonomous agents to develop a machinery control system for the Shape Deposition Manufacturing (SDM) Laboratory of the Robotics Institute at Carnegie Mellon University [21].

Other reported applications are found in laboratorial environment, namely the application of a multi-agent control system for shop floor assembly in the Novaflex manufacturing test bed at Uninova, Portugal [22]. The developed multi-agent system follows the CoBASA architecture [23], and was implemented by using the JADE platform. Another example is the implementation of a multi-agent manufacturing control system following the ADACOR holonic architecture [24] in a real laboratorial flexible manufacturing system at the Polytechnic Institute of Bragança, Portugal [25]. The agent-based control system was developed by using the JADE platform, aiming to increase the agility and re-configurability of production systems in dynamic and volatile environments. Yet another example is the ABAS (Assembly Automation Architecture) that was tested on a highly dynamic, reconfigurable micro-assembly station at Tampere University in Finland [26]. A holonic baggage handling system presented in [27] features a combination of multi-agent approach and IEC 61499 function blocks for low-level control. The OntoReA project aimed at developing a decentralized control architecture employing autonomous software agents extended with the reflective symbolic world model based on ontologies [28].

\subsection{Logistics and Material Handling}

Several applications of agent technology in scheduling and logistics optimization are reported in the literature. Table 2 summarizes these applications. 
Table 2. Industrial applications in logistics domain

\begin{tabular}{|c|c|c|c|}
\hline Designation / client & Companies involved & Domain & Type \\
\hline Air Liquide America & NuTech & Logistics optimization & Industry \\
\hline Tankers International & Magenta & Logistics scheduling & Industry \\
\hline $\begin{array}{l}\text { Airport ground service } \\
\text { operations }\end{array}$ & Magenta & $\begin{array}{l}\text { Modelling and } \\
\text { scheduling }\end{array}$ & Industry \\
\hline Taxi routing & Magenta & Real-time scheduling & Industry \\
\hline Truck routing & Magenta & Real-time scheduling & Industry \\
\hline Southwest Airlines & BiosGroup & $\begin{array}{l}\text { Ground floor operations } \\
\text { optimization }\end{array}$ & Industry \\
\hline ABX Logistics & Whitestein & $\begin{array}{l}\text { Real-time transport } \\
\text { optimization }\end{array}$ & Industry \\
\hline MAST & Rockwell & $\begin{array}{l}\text { Dynamic product } \\
\text { routing }\end{array}$ & $\begin{array}{l}\text { Simulation, Lab } \\
\text { test bed }\end{array}$ \\
\hline MAS-RFiD & $\begin{array}{l}\text { University of } \\
\text { Castilla-La Mancha }\end{array}$ & $\begin{array}{l}\text { Management of } \\
\text { logistics }\end{array}$ & Simulation \\
\hline MASDIMA & TAP, LIACC & $\begin{array}{l}\text { Airline operations } \\
\text { adaptation }\end{array}$ & Lab test bed \\
\hline
\end{tabular}

Nutech Solutions developed a multi-agent system solution for the Air Liquide America LP to reduce the production and distribution costs [29]. The implemented solution uses an ant-based strategy to manage the truck routes for delivering industrial and medical gases, adapting the production schedules to changing conditions, being responsive to unexpected events and customer demands.

Magenta Technology developed the agent-based system Ocean i-scheduler for the Tankers International company that operates one of the largest oil tanker pools in the world [30]. The objective of the agent-based logistics scheduling system is to dynamically schedule in real-time the cargo assignment to vessels in a very large crude carrier fleet (46 units) used to carry out transcontinental transportations of oil. Magenta Technology has also implemented a series of multi-agent applications of real-time scheduling for different domains, namely taxi routing (for a corporate taxi company in London, UK), truck routing (for Prologics and RusGlobal intercity cargo transportation companies, Moscow, Russia) and rent a car optimization (for Avis, London, UK) [18]. Another implementation of Magenta Technology in this area is the development of a multi-agent system for modelling airport ground service operations such as food delivery on board, air stairs bringing, pickup service and luggage delivery, aircraft cleanup, defreasing and some other services. The solution developed for a European aircraft producer also integrates RFiD technology [18].

The Southwest Airlines uses a software solution, developed by BiosGroup (recently acquired by the NuTech Solutions), based on swarm intelligence principles and integrating ant-based algorithms to get planes to available gates faster at the Sky Harbor International Airport in Phoenix, US [31]. The project was so successful that Southwest Airlines is now applying ant algorithms to the ticketing and check-in processes.

Whitestein Technologies has developed an agent-based solution for real-time transport optimization for the European logistics company ABX Logistics $\mathrm{GmbH}$, located at Duisburg, Germany, based on the Living Systems / Adaptive Transport 
Network (LS/ATN). The potential overall cost saving is $11,7 \%$, with an improvement of around $30 \%$ in the process efficiency [32].

Rockwell Automation developed an agent-based simulation environment, called MAST (Manufacturing Agent Simulation Tool), focusing on the dynamic product routing in manufacturing environments [33]. In MAST, developed by using the JADE platform, the agents represent basic transportation components, negotiate about optimal transportation routes in a redundant conveyor system, and allow online changes of the transportation paths layout. MAST was originally designed to demonstrate the benefits of agent technology in manufacturing domain but was posterior used to simulate two real scenarios: the holonic packing cell at the University of Cambridge, UK, and the pallet transfer system at the Automation and Control Institute (ACIN) of the Technical University of Vienna [33]. In the latter case MAST agents were also successfully deployed for the physical real-life control of the palette transfer system [34].

LIACC (Artificial Intelligence and Computer Science Laboratory) together with the Portuguese airline TAP are developing the MASDIMA (Multi Agent System for Disruption Management) project, by implementing a multi agent system that monitors and solves problems during the execution of the airline operation, being able to find the best integrated solution after a disruption has occurred [35].

The application of control methods based on multi-agent systems enhanced with RFiD to improve the management of a logistics/distribution center was reported in [36], using an experimental platform composed of a 3D simulation combined with a physical miniature model developed at the University of Castilla-La Mancha in Spain.

\subsection{Other Industrial Domains}

Several other industrial applications of agent technology are reported in the literature, as illustrated in Table 3.

The National Aeronautics and Space Agency (NASA) uses autonomous agents to balance multiple demands in satellites, such as staying on course, keeping experiments running, and dealing with the unexpected, thereby avoiding waste [37]. Also in the aerospace domain Magenta Technology developed for the Energia,

Table 3. Industrial applications in other domains

\begin{tabular}{|c|c|c|c|}
\hline Designation / client & Companies involved & Domain & Type \\
\hline NASA airspace satellites & NASA & $\begin{array}{l}\text { Management of } \\
\text { satellite demands }\end{array}$ & Industry \\
\hline $\begin{array}{l}\text { Energia, Korolev Rocket } \\
\text { and Space Corporation }\end{array}$ & Magenta & Dynamic rescheduling & Industry \\
\hline Aerogility & LostWax & $\begin{array}{l}\text { Intelligent decision } \\
\text { support }\end{array}$ & $\begin{array}{l}\text { Modelling and } \\
\text { simulation }\end{array}$ \\
\hline Turkey energy forecast & KKK Per. Bsk. & $\begin{array}{l}\text { Forecast energy } \\
\text { demands }\end{array}$ & Simulation \\
\hline $\begin{array}{l}\text { California Energy } \\
\text { Commission }\end{array}$ & AESC, Acronymics & $\begin{array}{l}\text { Coordination and } \\
\text { scheduling }\end{array}$ & Industry \\
\hline Large urban area & Rockwell & Water treatment & Simulation \\
\hline
\end{tabular}


Korolev Rocket and Space Corporation (the Russian National Space Agency) a multiagent cargo planning system for the international space station, supporting the dynamic reschedule of, for example, amount of fuel and water, products for cosmonauts' live support and some other goods that can be reallocated between spaceships flights [18]. LostWax developed Aerogility that uses multi-agent systems to model the aerospace aftermarkets, providing intelligent decision support to understand and manage the complex balance of aftermarkets resources [38].

Alternative Energy Systems Consultants (AESC) and Acronymics Inc. have developed for the California Energy Commission a multi-agent system for coordinating and scheduling operation of multiple distributed energy resources in the California energy market. Also in energy domain, a multi-agent system combined with swarm intelligence principles were used to forecast energy demands in Turkey until 2025 [39]. The applied ant colony optimization based algorithm has proved to behave better than others when comparing results from previous years.

Rockwell Automation developed a prototype agent-based application for water/waste water treatment to meet the requirements of water city demand in the most cost effective way [40].

\section{On-going Initiatives to Promote Industrial Agents}

The adoption of the agent technology by industry is promoted by several initiatives, namely those developed by some International Technical Committees and by some R\&D projects. This section discusses the recent developments in this area.

\subsection{On-going R\&D Funded Projects}

As an indicator of the importance of the multi-agent systems paradigm and technology to contribute to solve the requirements currently imposed to industry companies, namely in terms of modularity, flexibility and re-configurability, some few R\&D projects related to the deployment of this topic are running under the umbrella of the European Union (EU) FP7 programme. Table 4 summarizes the more representative projects running at the moment.

The analysis of the previous list allows verifying the importance of deployment multi-agent systems in industrial environments, e.g., applying multi-agent systems concepts in production lines for washing machines, as is expected for the GRACE project. This will allow for running industrial demonstrators that may contribute to attenuate the current scepticism of people from industry about the maturity and advantages of the agent technology in industrial environments.

Other R\&D projects addressing complementary topics to agent technology are also running promoted by the EU FP7 programme, namely AESOP (ArchitecturE for Service-Oriented Process - Monitoring and Control; www.aesop-mc.eu) that uses service-oriented computing principles for monitoring and control of process control applications, Self-Learning (www.selflearning.eu) that uses highly reliable and secure service-based self-learning solutions aiming the integration of control and maintenance of production systems, and MEDEIA (Model-Driven Embedded Systems Design Environment for the Industrial Automation Sector; www.medeia.eu) 
Table 4. Survey of European R\&D projects addressing industrial agent technology

\begin{tabular}{|c|c|}
\hline Title & Short description \\
\hline $\begin{array}{l}\text { GRACE } \\
\text { InteGration of pRocess and } \\
\text { quAlity Control using multi- } \\
\text { agEnt technology } \\
\text { (www.grace-project.org/) }\end{array}$ & $\begin{array}{l}\text { Use of multi-agent systems for integrating process and } \\
\text { quality control, and consider self-adaptive procedures into } \\
\text { control and diagnostic systems at local and global level } \\
\text { handling variation in process set-point and variables and } \\
\text { unplanned fluctuations of process/product parameters. The } \\
\text { validation of the project results will consider a demonstrator } \\
\text { in a washing machine production line. }\end{array}$ \\
\hline $\begin{array}{l}\text { IDEAS } \\
\text { Instantly Deployable } \\
\text { Evolvable Assembly Systems } \\
\text { (www.ideas-project.eu/) }\end{array}$ & $\begin{array}{l}\text { Development of demonstrators/technological solutions that } \\
\text { proves that assembly equipment can be highly adaptable, } \\
\text { applying the concepts of the Evolvable Assembly Systems } \\
\text { (EAS) paradigm. Focus in the agent-based fault-tolerant } \\
\text { control and reconfiguration aspects. }\end{array}$ \\
\hline $\begin{array}{l}\text { COSMOS } \\
\text { COSt-driven adaptive factory } \\
\text { based on MOdular } \\
\text { Selfcontained factory units } \\
\text { (EU ref. 246371) }\end{array}$ & $\begin{array}{l}\text { Design, development and implementation of a control system } \\
\text { for factory management with a flexible, modular and } \\
\text { evolvable automation approach which will permit to increase } \\
\text { the assembly factory productivity without losing flexibility. } \\
\text { Focus on wind turbine assembly process. }\end{array}$ \\
\hline $\begin{array}{l}\text { COLLIS.EUS } \\
\text { Soft Collaborative Intelligent } \\
\text { Systems } \\
\text { (FP7 ref. 255425) }\end{array}$ & $\begin{array}{l}\text { Development of collaborative information systems involving } \\
\text { multiple interacting agents and soft-computing techniques for } \\
\text { robotic and sensor systems. Covers a wide range of } \\
\text { applications such as manufacturing, scheduling, control, } \\
\text { diagnosis, logistics, energy and road traffic management. }\end{array}$ \\
\hline $\begin{array}{l}\text { CONET } \\
\text { Cooperative Objects Network } \\
\text { of Excellence } \\
\text { (www.cooperating- } \\
\text { objects.eu/) }\end{array}$ & $\begin{array}{l}\text { Development of a community in the area of Cooperating } \\
\text { Objects capable of conducting the needed research to achieve } \\
\text { the vision of combining embedded systems for robotics and } \\
\text { control, pervasive computing and wireless sensor networks. }\end{array}$ \\
\hline
\end{tabular}

that uses IEC 61499 reference models and 4DIAC as potential implementation platform to achieve the development of embedded control systems within the European industrial automation sector.

This research, development and deployment efforts have already started in the past with several projects promoted by EU and concluded with success, contributing for the evolution and maturity of industrial agents technology. A brief summary of some successful projects, already finished, is compiled in the next table.

The described overview shows the efforts promoted around Europe to disseminate and deploy the agent technology. In other world regions, the efforts are taken under different funding schemas. As examples, in the US the use of agent-based solutions is stimulated by the existence of partnerships and close cooperation between industry and universities. In Japan there is not a specific fund, or priority programme calls for multiagent systems but there are R\&D programmes funded by the domestic Japanese Intelligent Manufacturing Systems (IMS) center. An important remark should be addressed to the IMS programme (www.ims.org), which is an industry-led, international business innovation and $R \& D$ program established to develop a next generation of manufacturing and processing technologies, comprising companies and research institutions from the EU, Mexico, Korea, Switzerland and US. This programme had in 
Table 5. Past European R\&D projects addressing industrial agent technology

\begin{tabular}{|c|c|}
\hline Title & \\
\hline $\begin{array}{l}\text { Agent } \\
\text { A co- } \\
\text { based } \\
\text { (www }\end{array}$ & $\begin{array}{l}\text { Acted as a unifying focus for agent-based activities in } \\
\text { the different domains, with the long-term goal to put } \\
\text { Europe at the leading edge of international } \\
\text { competitiveness in this area. }\end{array}$ \\
\hline $\begin{array}{l}\text { I*PROMS } \\
\text { Network of } \\
\text { Innovative I }\end{array}$ & $\begin{array}{l}\text { Addressed innovative production by developing } \\
\text { concepts, tools and techniques enabling the creation } \\
\text { and operation of flexible, re-configurable, fault-tolerant } \\
\text { and user-friendly manufacturing systems that can react } \\
\text { to customer needs, environmental requirements, design } \\
\text { inputs, and material/process/labour availability to } \\
\text { manufacture high quality, cost-effective products. }\end{array}$ \\
\hline $\begin{array}{l}\text { PABADIS-PRON } \\
\text { PABADIS based } \\
\text { manufacturing sy } \\
\text { configurable ente }\end{array}$ & $\begin{array}{l}\text { Development of a new control design methodology } \\
\text { based on distributed intelligence, a new manufacturing } \\
\text { ontology, a new agent platform for field control, and a } \\
\text { new generation of RFIDs, field control devices and } \\
\text { ERP tools, enabling fast, flexible, and efficient } \\
\text { manufacturing. }\end{array}$ \\
\hline $\begin{array}{l}\text { MASCADA } \\
\text { Manufacturing } \\
\text { Capable of Man }\end{array}$ & $\begin{array}{l}\text { Development of agent-based manufacturing control } \\
\text { systems that are able to manage production change and } \\
\text { disturbance both effectively and efficiently, } \\
\text { safeguarding and/or maximizing the production } \\
\text { systems throughput. Autonomous and intelligent agents } \\
\text { were used to represent the factory components. }\end{array}$ \\
\hline 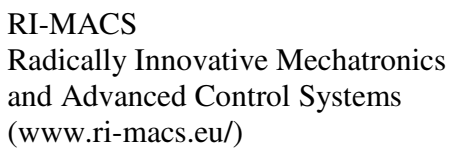 & $\begin{array}{l}\text { elopment of open approaches that uses multi-agent } \\
\text { ems, wireless technology and virtual engineering } \\
\text { gn methods to make manufacturing plants and } \\
\text { pments agile and reconfigurable. }\end{array}$ \\
\hline (www.socrades.eu) & $\begin{array}{l}\text { a design, execution and management } \\
\text { t-generation of industrial automation } \\
\text { ing the SOA paradigm, both at the } \\
\text { application level. Uses an agent-based } \\
\text { h to support the dynamic model-based } \\
\text { SoA-based automation platform. }\end{array}$ \\
\hline
\end{tabular}

the past a strong role in the dissemination of industrial agents, particularly within the framework on HMS.

\subsection{Initiatives to Disseminate Agent Technology}

In parallel to the on-going R\&D projects, other initiatives are being promoted, namely Technical Committees (TCs) focusing the activities related to industrial agents.

The IEEE IES TC on Industrial Agents (www.tcia.ieee-ies.org/) aims to provide a forum where researchers and application sector specialists can come together to continue the development and application of industrial agent technology in production, services and infrastructure sectors. The main roles of the technical committee are: 
- To provide forums to exchange ideas, knowledge, experience, learning and results in this area.

- To develop strategies for supporting systems developments and to assist in developing an integrated understanding of future industrial systems needs.

- To contribute for a wider dissemination and acceptance of industrial agents, both from the educational and industrial communities.

- To develop strategies for generating cross-cutting activities with other TCs.

An important effort is the development of cross-cutting activities with other groups or technical committees, namely with the IEEE IES TC on Industrial Informatics (www.ies-tcii.net), the IEEE IES TC on Standards (ieee-ies.org/tc/standards/), the VDI (Association of German Engineers) /VDE Technical Committee 5.15 on Agent Systems (www.vdi.de/3756.0.html), and also with the IEEE SMC TC on Distributed Systems (www.ieeesmc.org/technicalcommitteess/tc-dis.html). The most visible output of these cross-cutting activities is the joint organization of workshops and special sessions in international conferences in the field of industrial automation, namely the AAMAS, HoloMAS and IEEE IES conferences series. Other important initiatives are the organization of special issues published in international scientific journals, such as those included in the Journal of Intelligent Manufacturing, International Journal of Production Research and IEEE Transactions on Systems, Man and Cybernetics - Part C.

\section{Discussion and Conclusions}

The industrial agent technology is suitable to solve the current complex problems faced to industrial companies in terms of modularity, flexibility and reconfiguration. The previous sections of this paper have briefly introduced a picture about the current state of industrial applicability of agent technology and the main initiatives in course for its wider dissemination. This section intends to analyse and discuss the current situation, pointing out the future challenges faced to industrial agents.

The first conclusions from the previous survey are that the major focus of development and deployment of agent technology is centered in Europe. In other perspective, it is easily noticed that the industrial applications were very reduced, and the existing ones are mainly found in academic or laboratorial environments. In some domains the multi-agent systems are already widely spread, such as e-commerce, business applications, or logistics, but in industrial domain (and mainly in the manufacturing field) its adoption is rare. This is probably due to the inherent particular requirements imposed by this type of environments, namely in terms of real-time constraints and the integration with the physical hardware and legacy systems, which is not the case of the other domains, such as e-commerce and supply chains. However, an interesting observation is the recent interest of some commercial software companies in applying agent technology in industrial environments, namely Magenta Technology, NuTech Solutions and Whitestein Technologies. This growing interest, combined with the effort of some big automation technology providers, namely Rockwell Automation, is a good news and opens future perspectives for a wider adoption of the agent technology in industrial environments. 
Some reasons for this weak acceptance were already widely discussed in previous papers $[2,7,41]$. Briefly the main reasons are the distributed thinking (i.e., society and particularly industrial engineers are used to think in a centralized, hierarchical manner), the investments (the use of agent technology requires an immediate investment and the return only appears in the future when the need for reconfigurability occurs) and the industrial maturity of the technology (i.e., industrial companies don't want to be the first to use emergent technologies). Additionally, as stated in the Agent Link roadmap [3], the agent technology is still in its infancy and the agent programming skills are not yet widespread among commercial software developers. But more important than to identify the main reasons for the weak adoption of the agent technology in industry is to establish actions to be implemented to overcome them. For this purpose, the IEEE IES TC on Industrial Agents is conducting a survey analysis trying to identify the agenda of industrial agents for the next years. Using the preliminary feedback provided by this survey analysis and the authors' expertise in the field, it is possible to define some future challenges for the industrial agents. Besides the issues related to the improvement of technical details related to the multi-agent systems, namely in terms of ontologies and semantic web, scalability, and prediction and learning mechanisms, the main future trends for industrial agents are centred on:

i) Consideration of mature tools and development engineering methodologies that simplifies the engineer of agent-based systems (integrating the design, verification, simulation, and deployment phases) and also supporting technologies to run agent-based solutions, e.g., at low level control.

ii) Consider the integration with other technologies, namely the integration with the low-level control running in state-of-the-art PLCs running IEC61131-3 control programs or using the IEC 61499 standard since the direct connection with physical devices is usually mandatory in industrial environments. Aiming to address other integration vectors, namely the IT-vertical integration, the combination with web services should be considered to address the questions related to the interoperability.

iii) Consideration of bio-inspired techniques, and particularly self-organization and emergent behaviour, enhancing multi-agent systems to support the engineer of more robust, adaptive, reconfigurable and responsive systems.

iv) As highlight by industrial experts, the consideration of standardization issues in the development of agent-based solutions, namely the IEC 61131-3 and ISA 95 standards, is crucial. Note that the Foundation for Intelligent Physical Agents (FIPA) is a standard for the development of multi-agent systems, but it misses many of the particularities imposed by industrial environments.

However, the main challenge for the near future in the industrial agents field is centred in the effort to convince people from industry about the benefits of using agents, by providing demonstrators running in industry and return of investment (ROI) analysis, not only in terms of development costs but also in terms of operation and maintenance costs.

Currently, a roadmap survey is being conducted by the IEEE IES TC on Industrial Agents aiming to identify a R\&D and industrial agenda for the industrial agents for the next years, using the feedback of experts coming from academia and industry. 
Acknowledgments. The authors would like to thank all the members of the IEEE IES Technical Committee on Industrial Agents for their contribution in the on-going activities and particularly in the compilation of industrial agent-based applications.

\section{References}

1. Jennings, N., Bussman, S.: Agent-based Control Systems: Why Are They Suited to Engineering Complex Systems? IEEE Control Systems 23(3), 61-73 (2003)

2. Leitão, P.: Agent-based Distributed Manufacturing Control: A State-of-the-art Survey. Engineering Applications of Artificial Intelligence 22(7), 979-991 (2009)

3. Luck, M., McBurney, P., Shehory, O., Willmott, S. (eds.): Agent Technology: Computing as Interaction - A Roadmap for Agent-based Computing, AgentLink III (September 2005)

4. Wooldridge, M.: An Introduction to Multi-Agent Systems. John Wiley \& Sons, Chichester (2002)

5. Vrba, P., Tichy, P., Marik, V., Hall, K., Staron, R., Maturana, F.: Rockwell Automation's Holonic and Multi-agent Control Systems Compendium. IEEE Transactions on Systems, Man and Cybernetics - Part C: Applications and Reviews 41(1), 14-30 (2011)

6. Monostori, L., Váncza, J., Kumara, S.: Agent-Based Systems for Manufacturing. Annals of the CIRP 55/2, 697-720 (2006)

7. Pechoucek, M., Marik, V.: Industrial Deployment of Multi-agent Technologies: Review and Selected Case Studies. Autonomous Agents and Multi-agent Systems 17(13), 397-431 (2008)

8. Marik, V., Lazansky, J.: Industrial Applications of Agents Technologies. Control Engineering Practice 15, 1364-1380 (2007)

9. Colombo, A., Schoop, R., Neubert, R.: An Agent-based Intelligent Control Platform for Industrial Holonic Manufacturing Systems. IEEE Transactions on Industrial Electronics 53(1), 322-337 (2006)

10. Schild, K., Bussmann, S.: Self-Organization in Manufacturing Operations. Communications of the ACM 50(12), 74-79 (2007)

11. Brussel, H.V., Wyns, J., Valckenaers, P., Bongaerts, L.: Reference Architecture for Holonic Manufacturing Systems: PROSA. Computers in Industry 37(3), 255-274 (1998)

12. Bruckner, S., Wyns, J., Peeters, P., Kollingbaum, M.: Designing Agents for the Manufacturing Control. In: Proceedings of the Artificial Intelligence and Manufacturing Research Planning Workshop-State of the Art \& State of the Practice, pp. 40-46 (1998)

13. Marik, V., Vrba, P., Hall, K., Maturana, F.: Rockwell Automation Agents for Manufacturing. In: Proceedings of Industry Track of 4th International Joint Conference on Autonomous Agents and Multiagent Systems, pp. 107-113 (2005)

14. Maturana, F., Staron, R., Hall, K., Tichy, P., Slechta, P., Marík, V.: An Intelligent Agent Validation Architecture for Distributed Manufacturing Organizations. In: CamarinhaMatos, L. (ed.) Emerging Solutions for Future Manufacturing Systems, pp. 81-90. Springer, Heidelberg (2004)

15. Fletcher, M., McFarlane, D., Thorne, A., Jarvis, D., Lucas, A.: Evaluating a Holonic Packing Cell. In: Mařík, V., McFarlane, D., Valckenaers, P. (eds.) HoloMAS 2003. LNCS (LNAI), vol. 2744, pp. 246-257. Springer, Heidelberg (2003)

16. Monch, L., Stehli, M., Zimmermann, J.: FABMAS: An Agent-based System for Production Control of Semiconductor Manufacturing Process. In: Mařík, V., McFarlane, D., Valckenaers, P. (eds.) HoloMAS 2003. LNCS (LNAI), vol. 2744, pp. 258-267. Springer, Heidelberg (2003) 
17. Paolucci, M., Sacile, R.: Agent-Based Manufacturing and Control Systems: New Agile Manufacturing Solutions for Achieving Peak Performance. CRC Press, Boca Raton (2005)

18. Magenta Technologies, http://www. magenta-technology.com

19. Blanc, P., Demongodin, I., Castagna, P.: A Holonic Approach for Manufacturing Execution System Design: An industrial Application. Engineering Applications of Artificial Intelligence 21(3), 315-330 (2008)

20. Jacobi, S., Madrigal, C., Leon-Soto, E., Fischer, K.: AgentSteel: An Agent-based Online System for the Planning and Observation of Steel Production. In: Proc. of the 4th Int'1 Conference on Autonomous Agents and Multiagent Systems, pp. 114-119 (2005)

21. Wada, H., Sakuraba, Y., Negishi, M.: Machinery Control System using Autonomous Agents. In: Yokogawa Electric Corporation, Tokyo, Japan (1998)

22. Cândido, G., Barata, J.: A Multiagent Control System for Shop Foor Assembly. In: Mařík, V., Vyatkin, V., Colombo, A.W. (eds.) HoloMAS 2007. LNCS (LNAI), vol. 4659, pp. 293-302. Springer, Heidelberg (2007)

23. Barata, J., Camarinha-Matos, L.: Coalitions of Manufacturing Components for Shop Floor Agility - the CoBASA Architecture. International Journal of Networking and Virtual Organisations 2(1), 50-77 (2003)

24. Leitão, P., Restivo, F.: ADACOR: An Agile and Adaptive Holonic Architecture for Manufacturing Control. Computers in Industry 57(2), 121-130 (2006)

25. Leitão, P., Restivo, F.: Implementation of a Holonic Control System in a Flexible Manufacturing System. IEEE Transactions on Systems, Man and Cybernetics - Part C: Applications and Reviews 38(5), 699-709 (2008)

26. Lastra, J.L., Insaurralde, C., Colombo, A.W.: Agent-based Control for Desktop Assembly Factories. Collaborative Design and Planning for Digital Manufacturing, 265-291 (2009)

27. Black, G., Vyatkin, V.: Intelligent Component-Based Automation of Baggage Handling Systems with IEC 61499. IEEE Trans. on Automation Science and Engineering 7(2), 337$351(2010)$

28. Lepuschitz, W., Zoitl, A., Vallée, M., Merdan, M.: Towards Self-Reconfiguration of Manufacturing Systems using Automation Agents. Transactions on Systems, Man, and Cybernetics, Part C: Applications and Reviews 41(1), 52-69 (2011)

29. Harper, C., Davis, L.: Evolutionary Computation at American Air Liquide. In: Evolutionary Computation in Practice. Studies in Computational Intelligence, vol. 88, pp. 313-317. Springer, Heidelberg (2008)

30. Himoff, J., Skobelev, P., Wooldridge, M.: Magenta Technology: Multi-agent Systems for Industrial Logistics. In: Proceedings of the 4th International Conference on Autonomous Agents and Multiagent Systems, pp. 60-66 (2005)

31. Bonabeau, E., Meyer, C.: Swarm Intelligence: A Whole New Way to Think about Business. Harvard Business Review, 107-114 (May 2001)

32. Dorer, K., Calisti, M.: An Adaptive Solution to Dynamic Transport Optimization. In: Proc. of the 4th Int'l Conference on Autonomous Agents and Multiagent Systems, pp. 45$51(2005)$

33. Vrba, P., Mařík, V.: Capabilities of Dynamic Reconfiguration of Multiagent - based Industrial Control Systems. IEEE Transactions on Systems, Man, and Cybernetics, Part A: Systems and Humans 40(1), 1-11 (2010)

34. Vrba, P., Mařík, V., Merdan, M.: Physical Deployment of Agent-based Industrial Control Solutions: MAST Story. In: Proceedings of IEEE International Conference on Distributed Human-Machine Systems, pp. 133-139 (2008) 
35. Castro, A., Oliveira, E.: The Rationale behind the Development of an Airline Operations Control Centre using GAIA based Methodology. International Journal of Agent-Oriented Software Engineering 2(3), 350-377 (2008)

36. Encinas, J.C., García, A., Morenas, J.: Improvements in Operations Management Applied to a 3D Simulation Connected to a Physical Platform. Journal of Intelligent Manufacturing, 1-12 (July 2010)

37. Das, S., Gonsalves, P., Krikorian, R.: Multi-agent Planning and Scheduling Environment for Enhanced Spacecraft Autonomy. In: Proceedings of the 5th International Symposium on Artificial Intelligence, Robotics and Automation in Space (1999)

38. Dang, V.D., Osborn, S., Bridgeford, M., Vickers, G.: Aerogility - An Intelligent Decision Support System for Managing Service-based Aftermarkets. In: Proceedings of the 8th Int'1 Conference on Autonomous Agents and Multiagent Systems, pp. 1411-1412 (2009)

39. Ünler, A.: Improvement of Energy Demand Forecasts using Swarm Intelligence: The Case of Turkey with Projections to 2025. Energy Policy 36(6), 1937-1944 (2008)

40. Maturana, F., Staron, R.J., Hall, K.H., Tichý, P., Šlechta, P., Mařík, V.: An Intelligent Agent Validation Architecture for Distributed Manufacturing Organizations. In: Emerging Solutions for Future Manufacturing Systems, pp. 81-90. Springer, Boston (2005)

41. Marik, V., McFarlane, D.: Industrial Adoption of Agent-Based Technologies. IEEE Intelligent Systems 20(1), 27-35 (2005) 